Boston University School of Law Scholarly Commons at Boston University School of Law

Faculty Scholarship

2013

\title{
Did Legal Education Fail Health Reform? And How Health Law Can Help
}

Wendy K. Mariner

Boston University School of Law

Follow this and additional works at: https://scholarship.law.bu.edu/faculty_scholarship

Part of the Health Law and Policy Commons, and the Legal Education Commons

\section{Recommended Citation}

Wendy K. Mariner, Did Legal Education Fail Health Reform? And How Health Law Can Help, 10 Indiana Health Law Review 1 (2013). Available at: https://scholarship.law.bu.edu/faculty_scholarship/365

This Article is brought to you for free and open access by Scholarly Commons at Boston University School of Law. It has been accepted for inclusion in Faculty Scholarship by an authorized administrator of Scholarly Commons at Boston University School of Law. For more information, please contact lawlessa@bu.edu. 


\title{
Did Legal Education Fail Health Reform? AND How HEALTh LAW CAN HELP
}

\author{
Wendy K. Mariner*
}

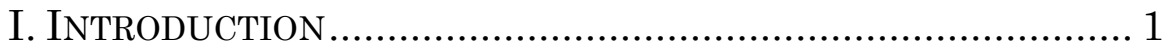

II. The ACA Challenge Was Not an Easy CASE ................ 3

III. Does Legal EDUCATION CONTRIBUTE to INEFFECTUAL SCHOLARSHIP OR PRACTICE?......................................... 11

IV. HEALth LAW OfFERS A MODEL FOR RETHINKING LEGAL EDUCATION, AT LEAST IN PART ....................................... 23

V. A BROADER Vision For HEALTH LAW .............................. 32

\section{INTRODUCTION}

The challenges to the constitutionality of several provisions of the Patient Protection and Affordable Care Act ${ }^{1}$ (ACA) should put an end to any question that health law is a field. ${ }^{2}$ In court, the issues were presented as

* JD, LLM, MPH; Edward R. Utley Professor of Health Law, Boston University School of Public Health; Professor of Law, Boston University School of Law; Professor of Socio-Medical Sciences and Community Medicine, Boston University School of Medicine. This article was first presented as the McDonald-Merrill-Ketcham Memorial Award Lecture at Indiana in April 2012. The author thanks all the participants in the anniversary conference for comments and suggestions.

1 See Nat'l Fed'n of Indep. Bus. v. Sebelius, 132 S. Ct. 2566 (2012). At least 28 cases challenged the individual mandate, the expanded eligibility requirements for Medicaid, and/or the use of federal funds to subsidize insurance coverage of contraception or abortion in the Patient Protection and Affordable Care Act of 2010, Pub. L. 111-148, § 1501, 124 Stat. 119, as amended by the Health Care and Education Reconciliation Act of 2010, Pub. L. 111-152, 124 Stat. 1029.

2 Several scholars have examined the nature of the health law field from different perspectives. See, e.g., George J. Annas, Health Law at the Turn of the Century: From White Dwarf to Red Giant, 21 ConN. L. REV. 551 (1989); M. Gregg Bloche, The Invention of Health Law, 91 CALIF. L. Rev. 247 (2003); Henry T. Greeley, Some Thoughts 
questions of constitutional law, specifically Congress's power to regulate commerce and to tax and spend for the general welfare. ${ }^{3}$ Nevertheless, analyzing whether those powers encompassed the minimum coverage requirement (also known as the individual mandate) and the Medicaid eligibility expansion necessitated more than passing knowledge of health care and health insurance. Constitutional scholars suddenly had to be health law experts. The arguments and resulting opinions, however, reflect significant gaps in knowledge about health insurance and the health care system in general.

This essay argues that this gap in knowledge matters and that it may offer lessons for improving legal education. Part 1 considers how ACA litigation arguments framed in traditional doctrinal terms missed much of the reality of health care. This suggests that the legal education may have failed to prepare advocates on both sides to identify and explain relevant arguments. Thus, Part 2 summarizes several relevant critiques of legal education. Part 3 then considers aspects of health law that offer promising responses to some of these critiques. Part 4 offers ideas for a broader vision for educating scholars and lawyers in health law. Most important, the legal profession, like the medical profession, faces a system in which services are increasingly costly and concentrated among those with the greatest resources. The history of health reform itself may

on Academic Health Law, 41 Wake Forest L. Rev. 391 (2006); Mark A. Hall, The History and Future of Health Law: An Essentialist View, 41 Wake Forest L. Rev. 347 (2006); Rand E. Rosenblatt, The Four Ages of Health Law, 14 HeALth MATRIX 155 (2004); S. Sandy Sandbar et al., Legal Medicine and Health Law Education, in LEGAL MEDiCINe 3 (S. Sandy Sandbar et al. eds., 7th ed. 2007); Walter Wadlington, Some Reflections on Teaching Law and Medicine in Law School Since the '60s, 14 Health Matrix 231 (2004); Wendy K. Mariner, Toward an Architecture of Health Law, 35 AM. J. L. \& MED. 67 (2009).

3 See U.S. ConsT. art. I, § 8, cl. 1, 3 ("Congress shall have Power To lay and collect Taxes . . . provide for the common Defence and general Welfare of the United States; . . . To regulate Commerce with foreign Nations, and among the several States, and with the Indian tribes."). 
hold lessons for the legal system and how to prepare lawyers to provide affordable services to all those in need.

\section{The ACA Challenge Was Not an EAsy Case}

When the ACA was first challenged, some constitutional scholars believed it would be an easy case. ${ }^{4}$ That assumption was belied by the fact that both ACA opponents and supporters believed it was an easy case. Nothing as path breaking as the ACA, the most significant national legislation in the health care field since the 1965 enactment of Medicare and Medicaid, was likely to be easy. Nonetheless, to many, the constitutional questions seemed straightforward when viewed from a traditional scholarly point of view. But, there were at least two points of view, based in large part on conceptions of federal power, and neither was adequate to argue or predict the outcome. Neither side fully understood how "commerce" and "spending" functioned in the health care system, so their arguments remained largely abstract and detached from the facts. To varying degrees, the Justices reflected a similar detachment in their opinions in the case.

By now, the arguments are well known and will not be repeated here. Suffice it to say that the arguments over the minimum coverage requirement parsed cases on Congress's Article I powers to tax and spend and to regulate commerce. ${ }^{5}$ The briefs, oral arguments, published articles, and the decision itself repeatedly analyzed Supreme Court decisions like Wickard ${ }^{6}{ }^{6}$ Lopez $_{,}{ }^{7}$ Raich, ${ }^{8}$ and Comstock. $^{9}$

4 See, e.g., David B. Rivkin, Jr. et al., A Healthy Debate: The Constitutionality of an Individual Mandate, 158 U. PA. L. REV. PENNUMBRA 93 (2009).

5 See, e.g., Randy E. Barnett, Commandeering the People: Why the Health Insurance Mandate is Unconstitutional, 5 N.Y.U. J. L. \& LiBERTY 581 (2011); Mark A. Hall, Commerce Clause Challenges to Health Reform, 159 U. PA. L. REv. 1825 (2011); Jack M. Balkin, Commerce, 109 Mich. L. REV. 1 (2010).

$6 \quad$ Wickard v. Filburn, 317 U.S. 111 (1942).

7 United States v. Lopez, 514 U.S. 549 (1995).

8 Gonzales v. Raich, 545 U.S. 1 (2005). 
None of these cases offered an exact precedent for the minimum coverage requirement. Congress had never imposed a precisely comparable requirement on individuals before. ${ }^{10}$ This alone made it a difficult case.

Of course, the fact that a law is novel does not make it unconstitutional. ${ }^{11}$ During the Great Depression, the Social Security Act was vigorously challenged as an unprecedented expansion of federal government authority to tax and spend - a point that Justice Ginsburg tried to make in the ACA oral argument. ${ }^{12}$ In 1937, the Social Security Act challengers argued that Congress's power to tax and spend for the general welfare did not include the power to pay oldage pensions only to the elderly. In Helvering v. Davis, the Supreme Court upheld the constitutionality of the Social Security tax on employees to provide pensions to the elderly, ${ }^{13}$ but the outcome was not a foregone conclusion. Justices McReynolds and Butler dissented on the grounds that the Act was "repugnant to the Tenth Amendment," 14 just as the ACA challengers argued that the individual mandate invades state sovereignty.

Writing for the majority, Justice Cardozo apparently felt compelled to explain the national need for federal financial aid. He did so in language that could apply to health insurance today:

9 United States v. Comstock, 130 S. Ct. 1949 (2010).

10 See Wendy K. Mariner, Leonard H. Glantz \& George J. Annas, Reframing Federalism-The Affordable Care Act (and Broccoli) in the Supreme Court, 367 NEW EnGL. J. MED. 12 (2012).

11 But see Sebelius, 132 S.Ct. at 2586 (Opinion of Roberts, C.J.) ("But sometimes 'the most telling indication of [a] severe constitutional problem ... is the lack of historical precedent' for Congress's action.").

12 See Transcript of Oral Argument at 57, Dep't of Health and Human Serv. v. Fla., 132 S. Ct. 2566 (2012) (No. 11-398), available at http://www.supremecourt.gov/oral_arguments/argument_transcripts/11398-Tuesday.pdf.

13 See Helvering v. Davis, 301 U.S. 619 (1937) (upholding the Social Security Act income tax on employees); see also Steward Mach. Co. v. Davis, 301 U.S. 548 (1937) (upholding Social Security Act excise tax on employers).

14 Helvering, 301 U.S. at 646 (Reynolds, J. and Butler, J., dissenting). 
Needs that were narrow or parochial a century ago may be interwoven in our day with the wellbeing of the nation. What is critical or urgent change with the times.

The purge of nation-wide calamity that began in 1929 has taught us many lessons. . . . Spreading from state to state, unemployment is an ill not particular but general, which may be checked, if Congress so determines, by the resources of the nation. ... But the ill is all one ... whether men are thrown out of work because there is no longer work to do or because the disabilities of age make them incapable of doing it. Rescue becomes necessary irrespective of the cause. The hope behind this statute is to save men and women from the rigors of the poor house .... ${ }^{15}$

This kind of contextual explanation was largely missing from the ACA litigation. ${ }^{16}$ Without it, however,

$15 \quad I d$. at 641.

16 An exception was Solicitor General Donald Verrilli's last minute plea at end of the last day of oral argument:

There is an important connection, a profound connection between that problem and liberty. And I do think it's important that we not lose sight of that . . . [because of the Medicaid expansion] there will be millions of people with chronic conditions like diabetes and heart disease, and as a result of the health care they will get, they will be unshackled from the disabilities that those diseases put on them and have the opportunity to enjoy the blessings of liberty. And the same will be true for - for a husband whose wife is diagnosed with breast cancer and who won't face the prospect of being forced into bankruptcy to try to get care for his wife and face the risk of having to raise his children alone, and I could multiply example after example after example.

Transcript of Oral Argument at 79-80, Dep't of Health and Human Serv. v. Fla., 132 S. Ct. 2566 (2012) (No. 11-400), available at http:// 
constitutional doctrine was not sufficient to resolve a matter of first impression either way. ${ }^{17}$ The Court's majority and dissenting opinions found little precedent to support their conclusions, despite occasionally tortured efforts to identify analogies and distinctions in earlier cases. But this should not mean that novel cases can be decided on the basis of the Justices' outcome preferences. Where doctrine alone cannot control, it becomes necessary to understand what the law at issue actually does, so that doctrine can be refined in principled ways. The novelty of the ACA meant applying doctrine - which itself was less than crystal clear - to complex issues of health care and health insurance financing. Resolving the constitutional question depended on knowledge of the health care system, insurance, and how insurance is used to pay for health care. Few, if any, constitutional scholars or practitioners had that knowledge. ${ }^{18}$

Counsel for the challengers framed the Commerce Clause claim most simply: that a requirement to obtain health coverage was simply a mandate to buy a commercial

www.supremecourt.gov/oral_arguments/argument_transcripts/11-400.

pdf.

17 See Wendy K. Mariner, George J. Annas \& Leonard H. Glantz, Can Congress Make You Buy Broccoli? And Why That's a Hard Question, 364 NEw EnGL. J. MED. 201 (2011); Mark A. Hall, Commerce Clause Challenges to Health Reform, 159 U. PA. L. REV. 1825 (2011).

18 Few people - lawyers and judges included - understand health insurance. And few of those who understand insurance in general understand health insurance, which functions quite differently from traditional indemnity insurance for things like cars and houses. See generally Wendy K. Mariner, Health Reform: What's Insurance Got to Do with It? Recognizing Health Insurance as a Separate Species of Insurance, 36 AM. J. L. \& MED. 436 (2010). Some economists with expertise in the health care industry readily understood the rationale for requiring almost everyone to participate in an insurance pool, and many supported the minimum coverage requirement. See Brief for Economic Scholars in Support of Petitioners Urging Reversal on the Minimum Coverage Issue at 2-5, U.S. Dep't of Health \& Human Serv. v. Fla., 132 S. Ct. 2566 (2012) (No. 11-398), available at http://www. americanbar.org/publications/preview_home/11-398.html; JONATHAN Gruber, HeAlth CARE Reform: What It Is, Why IT'S NECESSARY, How IT Works (2011). But they were not in a position to present a doctrinal argument. 
product, which amounted to requiring people to engage in commerce, not regulating any existing commerce. ${ }^{19}$ Of course, the ACA permits the coverage requirement to be satisfied by government-funded health benefit programs, such as Medicare, Medicaid, the Department of Veterans Affairs, and the Bureau of Indian Affairs, as well as employee group health plans. ${ }^{20}$ Nevertheless, Chief Justice Roberts and Justices Scalia, Kennedy, Thomas and Alito accepted the characterization of health insurance as a commercial product. ${ }^{21}$ Thus, if Congress could require individuals to buy this commercial product, then surely it could require individuals to buy other products. ${ }^{22}$ In light of

19 See Brief for State Respondents on the Minimum Coverage Provision at 15, U.S. Dep't of Health \& Human Serv. v. Fla., 132 S. Ct. 2566 (2012) (No. 11-398), available at http://www.americanbar.org/ publications/preview_home/11-398.html.

20 See 26 U.S.C. § 5000A(f) (2010); Paul Fronstin, Sources of Health Insurance and Characteristics of the Uninsured: Analysis of the March 2012 Current Population Survey, EMP’T BENEFIT RESEARCH Inst. ISSUE BRIEF No. 376, Sept. 2012, at 4, available at http://www.ebri.com/publications/ib/index.cfm?fa=ibDisp\&content_id=51 14 (noting that $18 \%$ of the nonelderly population was not covered by health insurance in 2011).

21 See generally Sebelius, 132 S. Ct. 2566. The Chief Justice and the Justices in the Joint Dissent described health insurance only as a commercial product, and then only in terms of traditional non-group indemnity insurance, which is underwritten so that it is actuarially fair: you only pay for your own personal risks. However, all but a small proportion of health insurance in the United States is either public benefit programs or private employee group insurance, which is not underwritten. See Fronstin, supra note 20, at 5 fig. 1; Paul Fronstin, Employment-Based Health Benefits: Trends in Access and Coverage, 1997-2010, EMP'T BENEFIT RESEARCH Inst. Issue BRIEF No. 370, Apr. 2012, available at http://www.ebri.com/publications/ib/index.cfm?fa= ibDisp\&content_id=5042. Only about 7 percent of the nonelderly U.S. population is covered by underwritten, individual (non-group) health insurance policies. Fronstin, supra note 20, at 5, fig. 1.

22 Sebelius, 132 S. Ct. at 2590 ("The mandate primarily affects healthy, often young adults who are less likely to need significant health care and have other priorities for spending their money."), at 2642 (Scalia, J., Kennedy, J., Thomas, J., Alito, J., dissenting). In fact, the major reason that people are uninsured is that they cannot afford the cost of insurance. SUMMARY HEALTH STATISTICS FOR THE U.S. Population: NATIONAL HEALth INTERVIEW SURVEY, 2009, U.S. DEP'T OF 
the breadth of commerce in today's national and global markets, such an expansive power looks more like the states' police power than a specific, enumerated federal power. These five Justices expressly sought to preserve the distinction between federal and state sovereignty. ${ }^{23}$ Their solution was to draw a bright line between those who are and are not active or engaged in interstate commerce, with federal authority to regulate commerce limited to the former. ${ }^{24}$ Although the Justices did not constrict the scope of Congress's commerce power, the majority would not expand it to include the power to require individuals to do something. ${ }^{25}$

Applying the active/inactive in commerce rule may not be as easy as the Justices seemed to assume. As Judge Sutton noted in his concurring opinion upholding the individual mandate for the sixth circuit Court of Appeals below, many instances of doing nothing can be characterized as doing something else and vice versa. ${ }^{26}$ The absence of any analysis of how the boundaries may blur deprives the majority's commerce clause opinions of some measure of persuasiveness. ${ }^{27}$

Justice Ginsburg, joined by Justices Breyer, Sotomayor and Kagan, dissented from the majority's commerce clause conclusions. Her opinion demonstrated a better understanding of the health care system. It viewed health insurance not as a fungible commercial product, but as a necessary means of paying for health care. ${ }^{28}$ Since virtually

HeAlth \& Human SERvs., 71 table 25 (2010), available at http://www.cdc.gov/nchs/data/series/sr_10/sr10_248.pdf.

23 Sebelius, 132 S. Ct. at 2575, 2642 (Scalia, J., Kennedy, J., Thomas, J., Alito, J., dissenting).

$24 \quad$ Id. at 2591.

$25 \quad I d$.

26 Thomas More Law Ctr. v. Obama, 651 F.3d 529, 560-63 (6th Cir. 2011) (Sutton, J., concurring), cert. denied, (2012) (abrogated by Sebelius, 132 S. Ct. 2566).

27 Sebelius, 132 S. Ct at 2625 (Ginsburg, J., concurring in part, concurring in the judgment in part, and dissenting in part) ("[I]f history is any guide, today's construction of the Commerce Clause will not endure.").

28 Id. at 2610 (Ginsburg, J.). 
everyone uses health care, they are already engaged in commerce, so the coverage requirement simply regulated how and when they pay for care. ${ }^{29}$ This, she argued, would not open the door to federal requirements that individuals buy cars or vegetables, because other products do not share health insurance's characteristics. ${ }^{30}$ This was a more complex argument to make, one requiring knowledge of the health care system.

The majority and minority Justices appeared to view the case through the lens of federalism. What was needed to convince a majority of the Justices to uphold the ACA's federal mandate under the Commerce Clause was a principled distinction between a requirement for health insurance coverage and a requirement to buy anything else - one that also served to distinguish the Commerce power from the police power. ${ }^{31}$ Such a distinction depended on facts specific to the health care system that would not apply to the purchase of all products. ${ }^{32}$ In short, to win the commerce clause argument, the government needed a limiting principle, and neither the government nor any Justice was able to articulate a sufficiently convincing one. ${ }^{33}$

29 Id. at 2620 (Ginsburg, J.) ("Persons subject to the mandate must now pay for medical care in advance (instead of at the point of service) and through insurance (instead of out of pocket).").

30 Id. at 2624 (Ginsburg, J.) ("One could call this concern the 'broccoli horrible," referring to the Chief Justice's mention of a mandate to buy green vegetables).

31 Id. at 2591, 2642 (Scalia, J., Kennedy, J., Thomas, J., Alito, J., dissenting).

32 The Brief of 104 Health Law Professors as Amici Curiae in Support of Petitioners at page three, Dep't of Health \& Human Serv. v. Fla., 132 S. Ct 2566 (2012) (No. 11-398), available at http://www .americanbar.org/content/dam/aba/publications/supreme_court_preview/ briefs/11-398_petitioneramcu104healthlawprofs.authcheckdam.pdf (offering a factual description) was submitted to provide the Court with those facts. Together with Mark A. Hall, the author helped draft the Brief, organized health law professors' participation, engaged counsel, and signed the Brief.

33 Sebelius, 132 S. Ct. at 2642 (Scalia, J., Kennedy, J., Thomas, J., Alito, J., dissenting). Paul Clement, representing the state challengers, argued that the federal government had no limiting principle for Congress's power to require individuals to buy commercial products, 
Instead, both the parties and the Justices argued the case in terms of abstract principles of federalism and barely looked beyond their own preferred interpretations of the Commerce power.

A better understanding of health insurance itself might have compelled the Justices to think more deeply about what was being regulated. In the absence of cogent explanations, the Court was left with an inadequate factual basis for determining whether the commerce power could apply to the minimum coverage requirement without implying that Congress could force people to enter markets involuntarily. ${ }^{34}$ Thus, the Justices' opinions tracked their

and began his oral argument by stating that the individual mandate is "an unprecedented effort by Congress to compel individuals to enter commerce." Transcript of Oral Argument at 55, Dep't of Health and Human Serv. v. Fla., 132 S. Ct. 2566 (2012) (No. 11-398). See Mariner, supra note 17, at 201-201 (noting the need for a persuasive limiting principle). This is not the first time that constitutional law scholars have misjudged the Supreme Court in health law cases. Professor Laurence Tribe argued on behalf of patients for the right to have physicians assist their suicides. Vacco v. Quill, 521 U.S. 793 (1997). At the time, colleagues suggested that it should be an easy win: the Supreme Court would find a constitutional right to physician-assisted suicide and strike down laws prohibiting physician assisted suicide, perhaps relying on Justice Kennedy's "mystery of human life" language in Planned Parenthood of Southeastern Pa. v. Casey, 505 U.S. 833, 851 (1992). But, the Court did not do so. Its decision made clear that the Court wanted a limiting principle on the purported right to assisted suicide, which the litigants did not provide. Wash. v. Glucksberg, 521 U.S. 702, 733 (1997).

34 The majority's decision on the Medicaid eligibility expansion also demonstrated incomplete knowledge of the structure and history of Medicaid, but the decisive factor appeared to be preserving state jurisdiction over the state's laws implementing Medicaid programs. Sebelius, 132 S. Ct. at 2601-8. The Chief Justice's opinion relied for the first time on the concept of coercion to find that the spending power precluded the federal government from ending all federal Medicaid funding of states that declined to adopt the newest category of eligible beneficiaries (adults under 65 years of age with incomes less than 133\% of the federal poverty level) added by the ACA. Id. at 2606-7; 42 U.S.C. $\S \S 1396(\mathrm{a})(10)(\mathrm{A})(\mathrm{i})(\mathrm{VIII}), 1396 \mathrm{c}$ (2012). 
views of the boundary between federal and state jurisdiction. ${ }^{35}$

The idea that the parties failed to appreciate relevant facts about the structure and financing of the health care system is significant, but not because a factual analysis should displace doctrinal analysis. Rather, doctrine requires interpretation when it is applied to new subject matter, and meaningful application of doctrine requires an accurate understanding of the subject matter. If the subject matter is misunderstood, the doctrine may be interpreted in incongruous ways, which may distort doctrine in its applications in other contexts. ${ }^{36}$ Regardless of whether such an analysis would have upheld the individual mandate, it should have produced a more robust and persuasive refinement of the definition of commerce.

\section{Does Legal EdUCATION CONTRIBUTE To INEFFECTUAL SCHOLARSHIP OR PRACTICE?}

Two conclusions can be drawn from the public and courtroom debate over the constitutionality of the individual

35 This is not to say that the Justices are motivated by public opinion or politics, which are not the same as ideology. See Lawrence Baum \& Neal Devins, Why the Supreme Court Cares About Elites, Not the American People, 98 GEO. L. J. 1515 (2010) (arguing that the Justices probably care more about the opinions of elites than the public).

36 For example, in his opinion on the Medicaid expansion, the Chief Justice called the addition of the new eligibility category "a shift in kind, not merely degree." Sebelius, 132 S. Ct. at 1575 . Yet, the opinion does not identify any relevant factual distinction between the eligibility categories originally in effect and added by pre-2010 amendments and the category added by the ACA. See generally Sara Rosenbaum \& Timothy Stoltzfus Jost, All Heat, No Light - The States' Medicaid Claims before the Supreme Court, 366 NEW ENG. J. MED. 487 (2012). Without a clear distinction, the decision invites confusion and future litigation over whether statutory amendments qualify as amendments or create entirely new programs. The Joint Dissent's characterization of generous federal funding as "coercive" is similarly unclear. Sebelius, 132 S. Ct. at 2643 (Scalia, J., Kennedy, J., Thomas, J., and Alito, J., dissenting). See Coll. Sav. Bank v. Fla. Prepaid Postsecondary Ed. Expense Bd., 527 U.S. 666 (1999); S.D. v. Dole, 483 U.S. 203 (1987). 
mandate: (1) health law issues pervade modern society; and (2) well trained lawyers failed to adequately explain or justify their positions on the constitutionality of the ACA. Both conclusions suggest that legal education may be missing an opportunity to prepare both scholars and practicing lawyers for effective careers today. Several critiques of legal education offer clues to what might contribute to this missed opportunity.

The critiques of interest here are a highly selective sample. ${ }^{37}$ I will not address the challenges that universities themselves face, which include increasing competition for students in a difficult economic environment with rising costs, income inequality, and high student loan debt, ${ }^{38}$

37 For comprehensive overviews, see BRIAN Z. TAMANAHA, FAILING LAW SCHOOLS (2012); Lauren Carasik, Renaissance or Retrenchment: Legal Education at a Crossroads, 44 IND. L. REV. 735 (2011). Well known studies of legal education include WILLIAM M. Sullivan, Anne Colby, Judith Welch Wegner, Lloyd Bond \& LEE S. Shulman, EduCATing LAWYERs: PREPARATion FOR THE PROFEssion OF LAW (The Carnegie Found. for the Advancement of Teaching ed. 2007) [hereinafter CARnEgIE REPORT]; AM. BAR Ass'N, SECTION ON LEGAL EDUCATION AND ADMISSIONS TO THE BAR \& TASK Force on LAW Schools and the Profession: NARRowing The GaP,

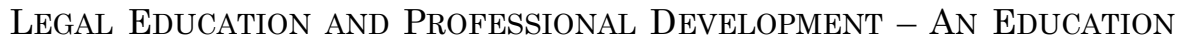
CONTINUUM (1992) [hereinafter MACCRATE REPORT]; AM. BAR Ass'N, SECTION ON LEGAL EdUCATION AND ADMissions TO THE BAR, REPORT AND RECOMMENDATIONS OF THE TASK FORCE ON LAWYER COMPETENCY: The Role OF LAW Schools (1979) [hereinafter CRAMPTON REPORT].

38 See U.S. GOV'T ACCOUNTABILITY OFF., REPORT TO CONGressional COMMitTEes - Higher EduCATION: Issues RELATED TO LAW SCHOOL COST AND ACCESS (2009), available at http://www.gao.gov/new.items/d1020.pdf. The Project on Student Debt at the Institute for College Access \& Success estimated that "two-thirds of college seniors who graduated in 2010 had student loan debt, with an average of $\$ 25,250$." Student Debt and the Class of 2010, ТHE Institute FOR COLLEGE ACCESS \& Success (Nov. 3, 2011), http://ticas.org/files/pub/classof2010.pdf. See The Student Loan "Debt Bomb": America's Next Mortgage-Style Economic Crisis?: A Report Prepared for the National Association of Consumer Bankruptcy Attorneys (NACBA), NACBA (Feb. 7, 2012), http://nacba.org/Portals/0/Documents/Student\%20Loan\%20Debt/020712 \%20NACBA\%20student\%20loan\%20debt\%20report.pdf (reporting that "Americans now owe more on student loans than on credit cards."). The 
technological advances, and pressure to disclose graduate employment data, ${ }^{39}$ reduce tuition, augment endowments, and demonstrate the value-added of a university education. ${ }^{40}$ Most law schools sit within universities, and their fate is tied to a significant degree with the fate of their university. ${ }^{41}$ But law schools face their own unique challenges. Perhaps the most pressure to conform to a traditional model of legal education comes from the rankings, whose criteria drive law schools' activities and metrics. ${ }^{42}$ But these are so well known, and almost

total amount of outstanding student loans exceeded $\$ 1$ trillion in 2011 . Id. at 1.

39 The American Bar Association Section of Legal Education and Admissions to the Bar, the accrediting body for U.S. law schools, adopted a requirement in June 2012, approved by the ABA House of Delegates in August 2012, that law schools disclose data on graduates' employment, student attrition, and scholarships conditioned on minimum grades. Debra Cassens Weiss, No Fudging: Revised Standard Bars Law Schools from Publishing Misleading Consumer Info, ABA JOURNAL (Aug. 2, 2012), http://www.abajournal.com/news/article/no_fudging_revised_standard_b ars_law_schools_from_publishing_misleadin (last visited Nov. 8, 2012).

40 In an address at the University of Michigan in January 2012, President Obama said:

"So, from now on, I'm telling Congress we should steer federal campus-based aid to those colleges that keep tuition affordable, provide good value, serve their students well. We are putting colleges on notice . ... If you can't stop tuition from going up, then the funding you get from taxpayers each year will go down." Obama in Ann Arbor: Text of the President's Speech on Affordability, ANNARBor.Com (Jan. 27, 2012), http://www.annarbor.com/news/obama-in-ann-arbor-text-of-the-

presidents-speech-on-college-affordability/ (last visited Nov. 8, 2012).

41 Gene R. Nichol, Rankings, Economic Challenge, and the Future of Legal Education, 61 J. LEGAL EDUC. 345 (2012).

42 See TAMANAHA, supra note 37, at 78-99; Michael Sauder \& Wendy Espeland, Fear of Falling: The Effect of U.S. NewS \& World Report Rankings on U.S. Law Schools - Grant Report 07-02, in L. SCH. ADMISSIONS COUNCIL REPORT SERIES 9-15 (2007), available at http://www.lsac.org/lsacresources/research/gr/gr-07-02.asp; Deborah L. Rhode, Legal Education: Professional Interests and Public Values, 34 IND. L. REV. 23, 25 (2000). 
universally lamented, that there is no need to mention them further. ${ }^{43}$

The best-known criticisms of legal education are what I call the Ivory Tower Critiques. These argue that legal education (1) is overly abstract and distant from real world problems, with too much emphasis on theory, (2) offers limited attention to practice issues, in particular, what lawyers do interacting with clients, prosecutors, businesses, administrative agencies, and other lawyers, and (3) produces scholarship of limited relevance to practitioners or judges. ${ }^{44}$

Legal education has been criticized for its distance from practice for decades, notably by Karl Llewellyn and Jerome Frank. ${ }^{45}$ A notorious example of the ivory tower critique is Justice Roberts' comment at a $4^{\text {th }}$ Circuit Judicial Conference in White Sulphur Springs, West Virginia, in June 2011. He reportedly said:

43 This essay also does not address styles of teaching or student learning, student stress, exams and methods of assessment, law school accreditation, or false advertising about law jobs after graduation, which has been much in the news recently. See, e.g., Rogelio A. Lasso, Is Our Students Learning? Using Assessments to Measure and Improve Law School Learning and Performance, 15 BARRY L. REV. 73 (2010); G. Andrew H. Benjamin et al., The Role of Legal Education in Producing Psychological Distress Among Law Students and Lawyers, 11 AM. B. Found. Res. J. 225 (1986); Ann L. Iijima, Lessons Learned: Legal Education and Law Student Dysfunction, 48 J. LEGAL EDUC. 524 (1998); David Segal, For Law Schools, a Price to Play the A.B.A.'s Way, N.Y. TIMES (Dec. 17, 2011), http://www.nytimes.com/2011/12/18/ business/for-law-schools-a-price-to-play-the-abas-way.html?pagewanted $=$ all\&_r $=0$.

$44 \quad$ See, e.g., Harry T. Edwards, The Growing Disjunction Between Legal Education and the Legal Profession, 91 Mich. L. REV. 34 (1992); Stewart Macauly, Law Schools and the World Outside Their Doors II: Some Notes on Two Recent Studies of the Chicago Bar, 32 J. LEGAL EDUC. 506 (1982); CARNEGIE REPORT, supra note 37, at 95-97; MACCRATE REPORT, supra note 37; CRAMPTON REPORT, supra note 37, at 3-4, 15-18.

45 See generally KARL N. Llewellyn, The Bramble Bush: Some Lectures ON LAW AND Its Study (1930); Jerome Frank, Why Not a Clinical Lawyer School?, 81 U. PA. L. REV. 907 (1933). 
Pick up a copy of any law review that you see, and the first article is likely to be, you know, the influence of Immanuel Kant on evidentiary approaches in $18^{\text {th }}$ Century Bulgaria, or something, which I'm sure was of great interest to the academic that wrote it, but isn't of much help to the bar. ${ }^{46}$

Perhaps this is why judges rarely read law review articles. Few law school professors would dispute the claim that their legal research, at least before tenure review, focuses on developing novel theories of law, which are read almost exclusively by other law professors. ${ }^{47}$

The grain of truth in the ivory tower critique - one that is relevant to the ACA litigation - is that the focus on theory may blind lawyers to the need for more specific and intensive examination of the subject matter to which theory and doctrine may apply. However, this does not mean that law schools ought to abandon rigorous teaching about theory and doctrine. ${ }^{48}$ Such teaching is foundational necessary, but not sufficient. Rather, the critique raises the perennial question of whether law schools should be training practitioners, as in the historical trade school model, or educating research scholars, as in the traditional Ph.D model. 49

46 Law Prof. Ifill Challenges Chief Justice Roberts' Take on Academic Scholarship, Am. Constitution Soc'Y BlOG (July 5, 2011), http://www.acslaw.org/acsblog/law-prof-ifill-challenges-chief-justiceroberts\%E2\%80\%99-take-on-academic-scholarship (last visited Nov. 8, 2012).

47 See Erwin Chemerinsky, Why Write?, 107 Mich. L. REV. 881, 885 (2009).

48 See, e.g., Richard A. Posner, The Deprofessionalization of Legal Training and Scholarship, 91 Mich. L. REV. 1921 (1993); George L. Priest, The Growth of Interdisciplinary Research and the Industrial Structure of the Production of Legal Ideas: A Reply to Judge Edwards, 91 Mich. L. REV. 1929 (1993); Lee C. Bollinger, The Mind in the Major American Law School, 91 Mich. L. REV. 2167 (1993).

49 See William R. Trail \& William D. Underwood, The Decline of Professional Legal Training and a Proposal for Its Revitalization in Professional Law Schools, 48 BAYLOR L. REV. 201 (1996). 
Law schools and lawyers have struggled with the question of which model suits legal education since the Civil War era. ${ }^{50}$ Nineteenth century German and other European university systems, which had established faculties in theology, philosophy, medicine, and law, apparently impressed several influential academics. ${ }^{51}$ The European conception of law as a science that required formal study distinguished the legal profession from a mere guild for craftsmen. ${ }^{52}$ It helped to characterize law as an academic discipline, instead of a trade, and worthy of placement within a university at a time when universities were becoming research institutions. It also offered an opportunity to develop an elite class of law professors capable of teaching the science - full-time academics who gradually replaced practicing lawyers as teachers. ${ }^{53}$ These attractions elevated research and scholarship over occupational training as the benchmark for academic standing. The development of formal legal education supplanted apprenticeship with practicing lawyers and culminated in today's model of a three-year program of graduate studies following a university undergraduate degree. ${ }^{54}$

50 Robert Stevens, LAW School: Legal Education IN AMERICA FROM THE 1850's TO THE 1980's 24, 51, 135, 265 (1983). See generally JAMES WiLlaRd HuRst, THE GROWTH OF AMERICAN LAW: THE LAW MAKERS (1950).

51 See Gail J. Hupper, The Rise of an Academic Doctorate in Law: Origins Through World War II, 49 AM. J. LEGAL HisT. 1, 8-9 (2007) (noting the Presidents of Harvard, Cornell and Chicago as examples). For an example of this influence, see Oliver Wendell Holmes, The Use and Meaning of Law Schools, and Their Methods of Instruction, 20 AM. L. REV. 919 (1886).

52 STEVENS, supra note 50, at 52-53; James E. Herget, The Influence of German Thought on American Jurisprudence, 1880-1918, in The Reception of Continental Ideas in THE Common LaW WORLD 1820-1920 203, 215 (Mathias Reimann ed., 1993).

53 Mathias Reimann, A Career in Itself-The German Professoriate as a Model for American Legal Academia, in THE RECEPTION OF CONTINENTAL IDEAS IN THE COMMON LAW WORLD 1820-1920 165, 188 (Mathias Reimann ed., 1993).

54 STEVENS, supra note 50, at 205, 209. 
Law professors have been expected to write scholarly articles, perhaps since then Dean of Harvard Law School urged it as one of three essential elements of the faculty in 1901. ${ }^{55}$ Yet, the quality of law faculty scholarship is highly variable. Despite Chief Justice Roberts' critique, there are thoughtful, relevant and useful law review articles (many of them in health law). ${ }^{56}$ However, the more practical and relevant they are, the less likely they are to provide support for tenure. If we are honest, we must concede that the pressure to be original in theory or, to a lesser extent, doctrine can produce irrelevant - sometimes ridiculous scholarship that would never be accepted in any other field of research. ${ }^{57}$ Furthermore, there is almost no supervision

55 James Barr Ames, The Vocation of the Law Professor, in LeCtuRES ON LEGAL History and Miscellaneous Legal Essays 364 (1913) (noting that the other elements are teaching, id. at 362, and influencing legislation and the development of the law, id. at 367).

56 See, e.g., Frank Pasquale, New York Times Financial Advice: Be an Unpaid Intern Through Your 20s (The Work till You're 100), BALKINIZATION (Nov. 20, 2011), http://balkin.blogspot.com/2011/11/newyork-times-financial-advice-be.html (noting Nicolas Terry's "cutting edge work on digital medical records"); Nicolas P. Terry, What's Wrong with Health Privacy? 5 J. Health \& Biomed. L. 1 (2009); Sidney D. Watson, The Road from Massachusetts to Missouri: Can Other States Replicate Massachusetts' Health Reform, 55 KAN. L. REV. 1331 (2007).

57 See, e.g., Colin Camerer et al., Regulation for Conservatives: Behavioral Economics and the Case for "Asymmetric Paternalism", 151 U. PA. L. REV. 1211 (2003) ("The fact that suicide is currently illegal marks a classic form of heavy-handed paternalism ... . An alternative policy . . . is to sanction suicide, but only after a mandatory cooling-off period. Such a policy might, for example, require a suicidal person to 'give notice' of the desire to commit suicide one month in advance with the ability to rescind the notice at any point during the intervening period."). The authors were apparently not aware that suicide was (and is) not illegal, so their factual premise was in error. Instead, they made an interesting theoretical argument for replacing the non-existent crime with an impractical alternative, since a majority of suicide attempts are spur of the moment decisions, which are not likely to be affected by any notice requirement. Institute of MEDicine, REDUCing SUICIDE: A NAtionaL ImPerative (S.K. Goldsmith et al. eds., 2002); Keith Hawton, Christopher Ware, Hamant Mistry, et al., Why Patients Choose Paracetamol for Self-Poisoning and Their Knowledge of Its 
of the accuracy of legal research. ${ }^{58}$ Student journal editors are well trained in paragraph structure and reference formatting, but are rarely familiar with the subject matter of the article they "edit." Few law journals use peer review to vet articles submitted for publication, so external experts have no opportunity to evaluate the premises, methods or conclusions of papers before publication. Moreover, few experts who are able to notice errors even read the journals. Law students typically rely on law review articles for their own research, so that errors embedded in journals are often perpetuated rather than corrected over time.

Law schools do some things well. The very first observation of the Carnegie Report was:

Within months of their arrival in law school, students demonstrate new capacities for understanding legal processes, for seeing both sides of legal arguments, for sifting through facts and precedents in search of the more plausible account, for using precise language, and for understanding the applications and conflicts of legal rules. Despite a wide variety of social backgrounds and undergraduate experiences, they are learning, in the parlance of legal education, to 'think like a lawyer.'59

Learning how to think like a lawyer is especially valuable for issue-spotting, but it has a downside. One

Dangers, 310 BRIT. MED. J. 164.1 (1995), available at http://www .bmj.com/content/310/6973/164.1.

58 There is some irony in the fact that legal scholarship was intended to resemble that of research for Ph.D.s in university departments, partly to justify legal studies as graduate level academic work, but did not adopt the same oversight and peer review requirements. See STEVEnS, supra note 50.

59 William M. Sullivan, Anne Colby, Judith Welch Wegner, Lloyd Bond \& Lee S. Shulman, Educating Lawyers: Preparation for the Profession of LaW, Summary 5 (The Carnegie Found. for the Advancement of Teaching ed. 2007) [hereinafter CARNEGIE Summary]. Critiques of the Carnegie Report soon proliferated. See, e.g., Kristen Holmquist, Challenging Carnegie, 61 J. LEGAL EDUC. 353 (2012). 
disadvantage arises from the use of casebooks, which publish highly edited versions of reported appellate cases stripped of factual details - to demonstrate legal principles. The Carnegie Report observes that:

most law schools emphasize the priority of analytic thinking, in which students learn to categorize and discuss persons and events in highly generalized terms. This emphasis on analysis and system has profound effects in shaping a legal frame of mind. At a deep, largely uncritical level, the students come to understand the law as a formal and rational system, however much its doctrines and rules may diverge from the common sense understandings of the lay person. ${ }^{60}$

The idea that law is a science - a set of (ideally neutral) principles that can be discerned with the appropriate analytic and conceptual skills - remains embedded in the core justification for legal education. ${ }^{61}$ US law schools narrowed the scope of the original European idea of law as science. Nineteenth century European curricula included history, economics, political theory, sociology, Roman law, and comparative law as part of the study of law. US law schools dropped those subjects for decades and only slowly reintroduced them in somewhat different forms, typically under specialized rubrics like law and economics and law and society. ${ }^{62}$ To be sure, critiques from successive movements - legal realism, positivism, critical legal theory, feminist theory, and social theory - have substantially

60 CARNEGIE SUMMARY, supra note 59 , at 5.

61 See generally STEVENS, supra note 50; Herget, supra note 52.

62 Stevens, supra note 50, at 277. See, e.g., RIChard A. Posner, Economic ANALYsis of LAW (8th ed. 2010); Sabine Frerichs, Studying Law, Economy and Society: A Short History of Socio-Legal Thinking, (U. Helsinki Research Paper Series, Legal Studies Research Paper Series No. 19, 2012), available at http://ssrn.com/abstract=2022891; MORTON HORWITZ, TRANSFORMATION OF AMERICAN LAW (1977); ROBERTO UNGER, LAW IN MODERN SOCIETY (1976). 
weakened law's claim to universality and neutrality.63 But the core claim is hard to give up. If law is simply the result of power struggles, what science remains for law schools to teach? Our students might be better off in departments of political science, economics, or sociology. 64

The solution cannot be to ignore theory or return to the days of apprenticeship training. However, insistence on developing novel and arcane theories divorced from the factors that influence law is driving scholarship farther away from making a meaningful contribution to jurisprudence. 65 The future of law schools may depend on a revolutionary rethinking of their structure and curriculum. Of course, law schools have not ignored these challenges. Nonetheless, a multitude of obstacles has stymied meaningful change. Most valuable reforms implemented so far, such as clinical seminars and externships, tend to be additions to a crowded curriculum.66 Moreover, they are often taught by clinical faculty, who complain of second class citizenship, often quite rightly. ${ }^{67}$ The real problem is that patching in new courses does little to change the perspective of legal education.

63 See, e.g., Duncan Kennedy, Legal Education And the REPROduction of Hierarchy: A PolemiC AGAinst THE SYSTEM (2004); Laura Kalman, Legal REAlism at Yale, 1927-1960 (1986); Robert W. Gordon, Historicism in Legal Scholarship, 90 YALE L. J. 1017 (1981); John Henry Schlegel, American Legal Realism and Empirical Social Science: From the Yale Experience, 28 Buffalo L. REv. 459 (1979).

64 See generally David Van Zandt et al., The Case Against Law School, N.Y. TiMES (July 21, 2011), http://www.nytimes.com/roomfor debate/2011/07/21/the-case-against-law-school?hp (discussing the need for law schools and their structure).

65 See Gary L. Blasi, What Lawyers Know: Lawyering Expertise, Cognitive Science, and the Functions of Theory, 45 J. LEGAL EDUC. 313 (1995).

66 See Margaret Martin Barry, Jon C. Dubin \& Peter A. Joy, Clinical Education for this Millennium: The Third Wave, 7 Clinical L. REV. 1 (2000).

67 See Elliott S. Milstein, Clinical Legal Education in the United States: In-House Clinics, Externships, and Simulations, 51 J. LEGAL EDUC. 375 (2001) (describing the range of programs). 
This brings me to a different set of criticisms of legal education, which I call the Social Justice Critique. This critique argues that many programmatic elements of the curriculum narrow the scope of legal analysis to one that preserves the status quo, perpetuates powerful elites ${ }^{68}$ and stifles creative thinking about the law and solutions to legal problems. Of particular concern is the categorization of required and elective courses. To social critics, the foundational courses of contracts, torts, civil procedure, and property immediately establish an image of law as primarily private case law. This private law emphasis reinforces the idea that corporate and property issues are the core of law, because they are the focus of learning how to think like lawyers. Directly or indirectly, it can train students to accept the existing structure of public and private institutions and financial relationships as normative and neutral in their effects, and thus to perpetuate the status quo. 69

Courses in legislation, administrative law, employment law, anti-discrimination law, and the like are typically relegated to elective status, creating the impression such subjects are peripheral in value. This can create a distorted picture of the legal landscape, especially since so much legal practice involves the drafting, interpretation, and application of legislation and regulations.

While the case method has substantial value in learning to think like a lawyer, the use of edited casebooks

68 Joan Williams notes that "one role of law school has been to train members of the elite to assume elite positions," and "Langdell invented his curriculum at Harvard to boss around other members of the elite," but adds that it now also serves as a pathway for non-elites to enter the elite class. Bob Gordon, Jack Schlegel, James May \& Joan Williams, Colloquium: Legal Education Then and Now: Changing Patterns in Legal Training and in the Relationship of Law Schools to the World Around Them, 46 AM. U. L. REV. 747, 769 (1998).

69 The expense of a legal education and the concentration of employment in corporate-oriented practice may exacerbate this effect, making access to justice unaffordable for low and middle-income Americans. See Gene R. Nichol, Jr., Judicial Abdication and Equal Access to the Civil Justice System, 60 CASE W. RES. L. REV. 325 (2010); Rhode, supra note 42 , at 23. 
sometimes undermines creative thinking. ${ }^{70}$ Some casebooks drain the life out of legal problems. Few contain facts to illuminate the context of legal problems. The discussion of cases leads students to focus on the legal issue, separate and apart from the social context. Problems are abstracted from their human dimension and considered only with respect to whether they fall within a rule. ${ }^{71}$ The Supreme Court's oral arguments exemplified a similar "bloodless" debate. It teaches that the ethical and social consequences of justifiable principles are beyond the scope of relevant consideration.

The absence of context - how and why legal problems arise in a particular society - gives students little opportunity for thinking about how to make strategic choices. ${ }^{72}$ Without practice at attention to context, law graduates may not recognize the complexity of their clients' problems. ${ }^{73}$ In light of the dynamic nature of many legal rules, and especially regulations, there is significant need for thinking carefully not only about what legal remedies are available, but also why only these and not others exist, and whether others could be developed. In this way, context can nurture useful new theories in law.

The Carnegie Report also notes that law schools pay less attention to the civic, professional, ethical and leadership roles of lawyers. ${ }^{74}$ Thus, graduates may miss important opportunities to exercise leadership to improve social

70 See generally Todd D. Rakoff \& Martha L. Minow, A Case for Another Case Method, 60 VAND. L. REV. 597 (2007) (critiquing the case method); Susan Sturm \& Lani Guinier, The Law School Matrix: Reforming Legal Education in a Culture of Competition and Conformity, 60 VAND. L. REV. 515 (2007) (critiquing the case method); Laura Kalman, To Hell with Langdell, 20 LAW \& Soc. INQUIRY 771 (1995) (critiquing the case method).

71 See, e.g., CARNEGIE REPORT, supra note 37, at 187.

72 See generally Steven L. Winter, A Clearing in the Forest: LAW, LIFE, AND Mind (2001).

73 See Kristen Holmquist, Challenging Carnegie, 61 J. LEGAL EDUC. 353 (2012).

74 See CARNEGIe REPORT, supra note 37, at 6. See also Angela P. Harris \& Marjorie Shultz, "A(nother) Critique of Pure Reason": Toward Civic Virtue in Legal Education, 45 STAN. L. REV. 1773 (1993). 
institutions..$^{75}$ Furthermore, a tight focus on legal doctrine can breed hammer-and-nail problems: when your only tool is a hammer, every problem looks like a nail. If law is your tool, you may tend to view law as the sole cause of - and therefore the only solution to - a problem. ${ }^{76}$ Sometimes, law is not the answer. Lawyers who fail to recognize complex sources of problems causes can miss the most effective solutions.

\section{HeAlth LAW OfFers A MODEL FOR RETHINKING LEGAL EDUCATION, AT LEAST IN PART}

The health law field suffers less from these criticisms than do most other legal fields and has several advantages that could be translated to other areas in the law curriculum. A particular advantage of health law in responding to critiques of legal education is that, as an applied area, it cannot avoid attention to real world problems. Moreover, these problems range across social and economic life from birth to death, exposing students to a wide array of both doctrinal and practical issues. ${ }^{77}$ After

75 See Karen H. Rothenberg, Recalibrating the Moral Compass: Expanding "Thinking Like a Lawyer" into "Thinking Like a Leader", 40 U. TOL. L. REV. 411 (2009).

76 For example, liability for injury is often cited as a major cause of problems like the high cost of some pharmaceuticals, the limited development of new vaccines, the price of medical malpractice premiums, and insufficient volunteers in emergencies, without examining other reasons, such as low return on investment, lack of market demand or resources, or better alternatives. See generally Aaron S. Kesselheim \& Kevin Outterson, Improving Antibiotic Markets for Long Term Sustainability, 11 Yale J. Health Pol'Y L. \& ETHICS 101 (2011); Charles H. Schultz \& George J. Annas, Altering the Standard of Care - Unnecessary and Dangerous, 59 ANnAls Emergency Med. 191 (2011); Marc A. Rodwin, Hak J. Chang \& Jeffrey Clausen, Malpractice Premiums and Physicians' Income: Perceptions of a Crisis Conflict with Empirical Evidence, 25 HEALTH AFF. 759 (2006); William M. Sage, Medical Malpractice Insurance and the Emperor's Clothes, 54 DePaUl L. REV. 463 (2005);

77 See Clark C. Havighurst, Health Care as a Laboratory for the Study of Law and Policy, 38 J. LEGAL ED. 499, 499 (1988) (noting that 
all, in 2010, national health expenditures were $\$ 2.6$ trillion dollars or $17.9 \%$ of GDP. 78 Thus, health law teaching and scholarship is firmly connected to the real world. Even theoretical scholarship in the health law field demands connection to facts. 79

Health law issues also invite - indeed demand attention to the larger context in which legal problems arise, because the consequences of interpreting some laws in one way rather than another can be significant when health is at stake.80 At the same time, the process of applying different laws can inspire new theories and valuable critiques of doctrine in light of their implications for solving legal problems. ${ }^{81}$ Ethical issues are especially salient, and not just in abortion, euthanasia, and treatment refusal. ${ }^{82}$ For instance, laws governing medical marijuana should take into account how effective medical treatments for different diseases are. Evaluating conflicts of interest among researchers requires familiarity with the way in

other fields "lack the magnitude, complexity and universality of health care").

78 Anne B. Martin et al., Growth In US Health Spending Remained Slow In 2010; Health Share Of Gross Domestic Product Was Unchanged From 2009, 31 HEALTH AFF. 208, 208-9 \& exhibit. 1 (2012).

79 To be sure, as in all fields, health law scholarship includes theory divorced from facts, but that is a different question of the quality and accuracy of scholarship, not its subject matter. See infra notes 9599 and accompanying text.

80 George J. AnNas, Standard OF CARE: The LAW OF AMERICAN BIOETHICS 246-249 (1993).

81 See, e.g., Wendy E. Parmet, Populations, Public Health, AND THE LAW (2009) (infusing constitutional doctrine with public health values); Nan D. Hunter, Risk Governance and Deliberative Democracy in Health Care, 97 Geo. L. J. 1 (2008); Mark A. Hall, Trust, Law, \& Medicine, 55 STAN. L. REV. 955 (2003).

82 Many biomedical ethics texts present issues that also raise legal questions. See, e.g., ETHiCAL Issues in Modern Medicine (Bonnie Steinbock, John Arras \& Alex John London, eds., 7th ed. 2008); GEORGE J. ANNAS, AMERICAN BIOETHICS xv (2005) (reiterating that "American law, not philosophy or medicine, is primarily responsible for the agenda, development and current state of American bioethics"). Some casebooks now combine both ethical and legal issues. See, e.g., Health CARE LAW AND EThics, (Mark A. Hall, Maryann Bobinski \& David Orentlicher, eds., 2007). 
which biomedical research is conducted. Larger questions of distributive justice can arise when interpreting or critiquing statutes that regulate financing and access to care. A recent example is the controversy over health insurance coverage of contraceptives, now required under the ACA. ${ }^{83}$ The study of health law can encourage critical thinking about whether a particular legal approach should be used instead of another, in light of their respective civic and ethical implications. ${ }^{84}$ In short, as Annas has noted, studying medical problems provokes thinking about what it means to be human and "therefore what rights and obligations humans should have." 85

Legal issues arise in clinical care, public health programs, biomedical research, corporate structures, product standards, conditions of employment, health insurance coverage and financing, responsibilities for children, and professional licensure, as well as the physician-patient relationship. Health law specialists must identify all laws that may affect a problem. Therefore, health law applies law from many legal domains: administrative law, ${ }^{86}$ antitrust, antidiscrimination,

83 FACT SHEET: Women's Preventive Services and Religious Institutions, OFFICE OF THE PRESS SEC'Y (Feb. 10, 2012), http://www.whitehouse.gov/the-press-office/2012/02/10/fact-sheetwomen-s-preventive-services-and-religious-institutions; Robert Pear, U.S. Clarifies Policy of Birth Control for Religious Groups, N.Y. TIMES (Mar. 16, 2012), http://www.nytimes.com/2012/03/17/health/policy/ obama-administration-says-birth-control-mandate-applies-to-religiousgroups-that-insure-themselves.html; Catholic Business Owners Win Temporary Halt in Birth Control Mandate, REUTERs (July 27, 2012), http://newsandinsight.thomsonreuters.com/Legal/News/2012/07_-

_July/Catholic_business_owners_win_temporary_halt_to_Obama_birth_ control_mandate/.

84 See, e.g., Wendy K. Mariner, The Affordable Care Act and Health Promotion: The Role of Insurance in Defining Responsibility for Health Risks and Costs, 50 Duquesne L. REV. 271 (2012); Nicole Huberfeld, Federalizing Medicaid, 14 U. PA. J. Const. L. 431 (2011).

85 ANNAS, supra note 80, at 248.

86 A remarkable number of administrative agencies deal with health issues, including the Centers for Medicare and Medicaid, the Food and Agriculture Drug Administration, the Environmental 
constitutional law, contracts, corporations, criminal law, employment law, environmental law, insurance, international law, patents, privacy, and torts. So many different legal issues are connected to health that one might devote one or more semesters to them without sacrificing attention to important doctrinal learning, not only because the field is so broad, but also because doctrine taught in other courses can be learned within health law courses. 87

Applied fields have many opportunities to use problemoriented methods, which require students to identify the different legal tools that could be brought to bear on a real problem. This approach is closer to law practice than the study of domains of law or legal doctrine in the abstract. 88 Many health law professors have embraced practical lawyering skills somewhat more enthusiastically than most other specialties, offering students opportunities to work with law firms, hospitals, and legislatures, and to draft briefs amici curiae for relevant litigation. 89 Northeastern University School of Law is a leading example of experiential (practice-based) legal education; its cooperative program places law students in supervised

Protection Agency, the Occupational Safety and Health Administration, as well as state departments of health and environmental protection.

87 ANNAS, supra note 80, at 258.

88 See, e.g., Jonathan Todres, Beyond the Case Method: Teaching Transactional Law Skills in the Classroom, 37 J. L. MED. \& ETHICs 375 (2009).

89 This is not to suggest that health law teaching is always successful. The American Health Lawyers Association surveyed 94 health law practitioners in 2011 on their evaluations of new health law graduates. Preliminary results suggest that those surveyed reported that the new associates were best at legal research, analytical and reasoning skills, and advocacy and persuasion. They were less well prepared in writing skills, strategic thinking, problem solving, administrative law and the regulatory process. Kevin Outterson, Associate Professor of Law at Boston University, Presentation at the American Health Law Association Annual Meeting (June 25, 2012) (copy on file with author). 
practice settings, especially in public interest, international and human rights law. 90

Scholarship in health law is often relevant to policymakers. Health law issues appear in the news almost daily, as well as in legislatures and courtrooms around the country. Keeping abreast of the field necessarily requires paying attention to real world developments, and this includes problems of economics, politics, and moral reasoning. One way to influence the development of the law is to reach policy-makers, and health law scholars often publish in medical and policy journals, such as Health Affairs and the New England Journal of Medicine, which policy-makers are likely to read. ${ }^{91}$ Empirical research is also growing in health law, perhaps because of its emphasis on effective solutions to real problems. ${ }^{92}$ Opportunities for

90 About Northeastern University Law School, NORTHEASTERN UNIV., http://www.northeastern.edu/law/about/index.html (last visited Nov. 1, 2012); STEVENS, supra note 50, at 233, 241.

91 See, e.g., Timothy S. Jost, Employers and the Exchanges Under the Small Business Health Options Program: Examining the Potential and the Pitfalls, 31(2) Health AfF. 267 (Feb. 2012); Mark A. Hall, Wenke Hwang \& Allison Snow Jones, Model Safety-Net Programs Could Care for the Uninsured at One-Half the Cost of Medicaid or Private Insurance, 20 HEALTH AFF. 1698 (Sept. 2011); David A. Hyman \& William M. Sage, Do Health Reform and Malpractice Reform Fit Together?, American Enterprise Institute for Public Policy Research Working Paper 2011-02 (2011), available at http://www.aei.org/files/ 2011/04/01/2011-04-Hyman-Sage.pdf.

92 See Martin Partington, Empirical Legal Research and PolicyMaking, in THE OXFORD HANDBOOK OF EMPIRICAL LEGAL RESEARCH 1002 (Peter Cane \& Herbert M. Kritzer, eds. 2010) (arguing that empirical legal research should be valuable to policy makers, because it can provide evidence to identify gaps and weaknesses in current law, strategies for change, and areas where legislation is not likely to solves problems, id at 2003-4). For examples of empirical research in health law, see Nicolas P. Terry, Meaningful Adoption: What We Know and Think We Know about the Financing, Effectiveness, Quality and Safety of Electronic Medical Records, J. LEGAL MEDICINE (forthcoming 2012); Ann Hwang, Sara Rosenbaum \& Benjamin D. Sommers, Creation of State Basic Health Programs Would Lead to 4 Percent Fewer People Churning Between Medicaid and Exchanges, 31(6) Health AfF. 1314 (June 2012); Bernard Black, Charles Silver, David A. Hyman \& William 
employment in health law grow almost as fast as the health system, and this growth should accelerate as the ACA is implemented. New ideas and new courses have entered the curriculum most often when there was a need for new legal skills. For example, in the 1800's, Harvard Law School prepared its graduates to become legislators and social leaders by teaching the Federalist and also political science. 93 After the New Deal created new administrative agencies, law schools began teaching administrative law and policy to prepare graduates to lead those agencies. ${ }^{94}$ When the administrations of Presidents Reagan, George H.W. Bush, and George W. Bush favored more libertarian approaches to governing, they began to appoint lawyers trained in law and economics as well as Federalist Society members to federal administrative positions and judgeships. ${ }^{95}$ Today, there should be expanded opportunities for employment for lawyers who know the health care system, as well as those in environmental law. These opportunities exist not only in private law practice, but also in government agencies, legislatures, and commercial and nonprofit health-related organizations. Health law training can prepare lawyers for all these options, because it includes systematic knowledge of health systems.

Of course, the health law field is not without its own problems. The most daunting is its scope. ${ }^{96} \mathrm{It}$ is difficult to master all the relevant legal domains and avoid

Sage, Stability, Not Crisis: Medical Malpractice Claim Outcomes in Texas, 1988-2002, 2 J. EMPIRICAL LEGAL STUD. 207 (2005).

93 R. Kent Newmyer, Harvard Law School, New England Legal Culture, and the Antebellum Origins of American Jurisprudence, in The Constitution And American Life 154-175 (David Thelen ed., 1988).

94 Charles Epp, The Rights Revolution: LaWyers, ACtivists AND SuPREME COURTS IN COMPARATIVE PERSPECTIVE 197 (1998).

95 Steven M. Teles, The Rise of the Conservative Legal MOVEMENT: The BATTLE FOR CONTROL OF THE LAW 141, 158 (2008).

96 Wendy K. Mariner, Toward an Architecture of Health Law, 35 AM. J. L. \& MED. 67, 68 (2009). 
dilettantism. ${ }^{97}$ As a result, the quality of health law scholarship remains uneven. Some of the health law field's advantages may undermine rigor in scholarship. For example, empirical and other research that is funded by external donors may be influenced, perhaps unwittingly, by the money itself or the donor's goals, in the same ways that conflicts of interest can affect biomedical research.98 If funding is available for drafting new laws limiting liability, for example, but not for laws reducing the risk of harm, then more recommendations for liability limits are likely to be produced.

Health law often considers valuable insights from other disciplines, which should expand and enhance our view of the law and its effects. At times, however, viewing a legal issue only from a single disciplinary perspective can distort the analysis. Learning a little bit about economics, sociology or epidemiology, for example, can be a dangerous thing, if one begins to view all law from the perspective of that discipline alone. 99 In some cases, the new disciplinary perspective overtakes the law, reversing their roles. If that happens, the law can be seen simply as a tool to achieve the

97 In this respect, health law resembles emergency medicine, which requires knowledge of many medical specialties. The medical profession did not recognize emergency medicine as a distinct specialty for many years, partly because of its applied nature. See generally BRIAN J. Zink, ANYONE, ANYThing, ANYTIME-A History of EMERGENCY MEDICINE (2005).

98 The potential for conflicts of interest to create bias in biomedical research is well known. See, e.g., BERNARD LO, CONFLICTS OF Interest in Medical Research, Education, and Practice 195 (2009); Lee Friedman \& Elihu Richter, Relationship Between Conflicts of Interest and Research Results, 19 J. GEN. InTERnAL MED. 51 (2004); David Korn, Conflicts of Interest in Biomedical Research, 284 JAMA 2234 (2000); Dennis Thompson, Understanding Financial Conflicts of Interest, 329 NEW ENGL. J. MED. 573 (1993).

99 Stevens call this a "monocausal vision of the legal system." Stevens, supra note 50, at 272. See Ronald Chen \& Jon Hanson, Categorically Biased: The Influence of Knowledge Structures on Law and Legal Theory, 77 S. CAL. L. REV. 1103, 1133-39 (2003) (discussing how various personal and experiential schemas bias how we process information). 
goals of the other discipline, rather than a field with its own values and goals. 100

A different kind of bias may arise from one's philosophy of law or personal ideology. ${ }^{101}$ Although this is hardly unique to health law, health law scholarship may have more opportunities to fall prey to such bias, because it examines so many controversial social issues on which most people have strong opinions. It can be difficult to maintain a truly neutral perspective when analyzing laws or doctrines that affect the outcome of an issue important to the scholar. ${ }^{102}$ This is especially risky in applied fields like health law, where scholars may have a somewhat shallow understanding of the doctrine that applies to a hot-button issue and neglect to adequately analyze precedent and arguments that contradict a preferred interpretation. ${ }^{103}$ It

100 See David M. Trubek, The Place of Law and Social Science in the Structure of Legal Education, 35 J. LEGAL EDUC. 483 (1985). For example, the concepts of law and economics added a valuable perspective to legal analysis, but some adherents began to argue that law itself should conform to classical microeconomic theory. TELES, supra note 95, at 90-134. See AnN SOUTHWORTh, LAWYERS OF THE Right: Professionalizing the Conservative CoAlition 130-48 (2008) (describing the Federalist Society and the development of a conservative movement to change constitutional law). Another example can be found in public health law, where some scholars see the law as simply a tool to achieve health, regardless of other goals, such as justice and liberty. For a critique of this approach, see Wendy K. Mariner, Law and Public Health: Beyond Emergency Preparedness, 38 J. Health L. 247, 279-284 (2005).

101 See Norman G. Levinsky, Nonfinancial Conflicts of Interest in Research, 347 NEW ENGL. J. MED. 759 (2002).

102 See Daniel Kahneman, Thinking, Fast And Slow (2011) (describing theories and empirical research in psychology demonstrating how people often fail to analyze complex questions or accept evidence that contradicts their experience, biases or preferences).

103 Compare, e.g., Leonard H. Glantz \& George J. Annas, Handguns, Health, and the Second Amendment, 360 New EnGL. J. MED. 2360, 2361-63 (2009) (noting that the Supreme Court had not specifically decided whether the Second Amendment protected an individual or collective right to bear arms before District of Columbia v. Heller, 554 U.S. 570 (2008)), with Lawrence O. Gostin, The Constitutional Right to Bear Arms, 300 JAMA 1575 (2008) (noting that earlier cases were understood to limit the Second Amendment's protection to a collective right to maintain a militia). 
can be easy to convince ourselves that our preferred understanding of doctrine or precedent is the indisputably correct interpretation, especially where precedent is limited and open to interpretation. ${ }^{104}$ Some constitutional law scholars seem to have succumbed to this error in arguing about the scope of the Commerce Clause during the ACA litigation. ${ }^{105}$

Strong convictions about the correct interpretation of law can lead to advocacy. Of course, practicing lawyers properly advocate for their clients, and make clear that they are doing so. Scholarship is a different matter. It should offer honest, balanced analysis that recognizes different approaches and opinions. Scholarship does not preclude arguing for a particular interpretation or approach, but arguments are not statements of fact. There should be no hidden agendas in scholarship. When scholarship presents a preferred interpretation as fact or doctrine, it is poor scholarship. ${ }^{106}$ It may also cross the line into advocacy. If it

104 See, e.g., Memorandum from Jay Bybee, Assistant Attorney General of the United States for Alberto Gonzales, Counsel to the President (Aug. 1, 2002), available at http://dspace.wrlc.org/doc/bitstream/2041/70964/00355_020801_001displ ay.pdf; Memorandum from Jay S. Bybee, Assistant Attorney General of the United States for John Rizzo, Acting General Counsel of the Central Intelligence Agency (Aug. 1, 2002), available at http://dspace.wrlc. org/doc/bitstream/2041/70967/00355_020801_004display.pdf;

Memorandum from John C. Yoo, Deputy Assistant Attorney General, U.S. Department of Justice for William J. Haynes, II, General Counsel of the [U.S.] Department of Defense (Mar. 14, 2003), available at http://www.aclu.org/pdfs/safefree/yoo_army_torture_memo.pdf. See also JACK Goldsmith, THE TERROR PRESIDENCY (2007) (noting that these memorandums were later withdrawn).

105 Brian Leiter, Why did most legal scholars, liberal and conservative, fail to realize that the Supreme Court might take the silly arguments against the "individual mandate" seriously?, Brian Leiter's Law School Reports, available at http://leiterlawschool.typepad.com/ leiter/2012/04/why-did-most-legal-scholars-liberal-and-conservative-failto-realize-that-the-supreme-court-might-ta.html.

106 See for example Matthew L. Myers, Protecting Public Health by Strengthening the Food and Drug Administration's Authority over Tobacco Products, 343 NEw EngL. J. MED. 1806, 1808 (2000), for a discussion of how health lawyers believed, before the Food Drug and 
fails to disclose its advocacy goal, it can be seen as deceptive.

Scholars in the health law field have many tempting opportunities to write as advocates, because the health care system has so many issues of public importance on which people hold strong views. When scholars write articles, as opposed to advocacy or opinion pieces, on such topics, it is essential to remain open-minded and use one's critical analysis skills to recognize facts and arguments that challenge one's preferred outcome. This is especially important in health law, where decision makers may rely on health law scholarship to develop policy far more than they may rely on more esoteric scholarship on legal theory.

\section{A BROADER Vision FOR HEALTH LAW}

The Carnegie Report's first recommendation for improving legal education was to develop an integrated curriculum with 3 goals:

(1) the teaching of legal doctrine and analysis, which provides the basis for professional growth; (2) introduction to the several facets of practice included under the rubric of lawyering, leading to acting with responsibility for clients; and (3) exploration and assumption of the identity, values and dispositions consonant with the fundamental purposes of the legal profession. Integrating the three parts of legal education would better prepare students for the varied demands of professional legal work. 107

Cosmetic Act was amended to authorize the FDA to regulate tobacco, that the FDA already had statutory authority to regulate the tobacco industry and were surprised when the Supreme Court found that the FDA's authority - to approve only safe and effective new drugs - could not include tobacco in FDA v. Brown \& Williamson Tobacco Corp., 529 U.S. 120 (2000).

107 William M. Sullivan, AnNe Colby, Judith Welch Wegner, Lloyd Bond \& LeE S. Shulman, Educating LaWyers: Preparation 
One need not accept the Report's specific critiques or conclusions to recognize that health law offers a good model for a law school curriculum that integrates knowledge, analysis, theory, attention to context, practical application, values, and meaningful change.

A common theme underlying many proposals to reform legal education is that of increasing attention to the role of lawyers in society: to inculcate in students an understanding of the obligation of lawyers to the rule of law and the importance of justice overall. Too often the lawyer's role is understood narrowly, focusing only on the ethics of the private practice of law. ${ }^{108}$ If law is a profession, it must stand for something, and that something should be justice. ${ }^{109}$ Moreover, justice is for everyone, not only a client. So, a deeper understanding of the role of lawyers and the rule of law requires expanding our intellectual horizons to encompass the role of law in society.

This begs the question of what law is; a question well beyond the scope of this essay. Nevertheless, it is worth asking whether we can honestly say that law is a science with formal rules and neutral, objective principles of justice. I think not - as long as there are differing theories of justice and no universally accepted standard for choosing among them. ${ }^{110}$ The periodic waves of jurisprudential scholarship

For the Profession of LAW, Summary 8 (The Carnegie Found. for the Advancement of Teaching ed. 2007) [hereinafter CARNEGIE SUMmARY]. The Carnegie Report recognized the difficulty of implementing its recommendations. Remaking a curriculum is a complicated undertaking that may require years of work. Human beings are naturally reluctant to change what they are doing. See also Carsik, supra note 37 , at 814 (noting that in academia, curriculum changes can be perceived as a threat to the value of the faculty's work, while there may also be personal rewards for working with other faculty, learning their perspectives, and discovering new insights).

108 See Bethany Rubin Henderson, Asking the Lost Question: What Is the Purpose of Law School?, 53 J. LEGAL EDUC. 48 (2003).

109 CARNEGIE REPORT, supra note 37, at 131; M MCCRATE REPORT, supra note 37 , at 140-41 ("striving to promote justice, fairness, and morality" is one of the four fundamental values of the legal profession).

110 The vast literature on theories of justice is testimony to the multitude of different perspectives. See, e.g., MichaEL J. SANDEL, 
from different perspectives are evidence of an unsettled system.

So, what can we teach? If law constructs rules based on justice and fairness, we can, and often do, turn to political economy, economics, social theory, and moral philosophy to try to determine what is fair. Each of these fields offers important insights and perspectives to enrich our thinking. But, each also has its own ambiguities and internal conflicts, so that the same lack of consensus can reemerge in different jargon: no ultimate neutral standard of justice. Law professors, not fully expert in those fields, can be understandably nervous about relying on any single approach for ultimate insights.

For me, the only realistic answer is to live with the messiness of law. It means giving up the idea that there necessarily is a right answer, while continuing the search. We need to keep asking why we should accept a legal principle. What purpose does it serve, not only in principle, but in people's daily lives? It means analyzing doctrine in the context of the world in which law applies and its consequences for real people. It means recognizing the need for change, interacting with people who are affected by the law (and the absence of law), and, most importantly, explicitly considering the social, financial, and moral implications of law - not merely in theory, but as experienced by all those affected. ${ }^{111}$

In his President's Report to the Board of Overseers of Harvard University for 1981-82, Derek Bok aptly compared the legal system to the health care system, finding both to be increasingly sophisticated, but also complex, costly and

Justice (2009); CATHARINe A. MACKInNON, TOWARD A FEMinist THEORY OF THE STATE (1989); RONALD DWORKIN, LAW's EMPIRE (1986); JOHN HART Ely, DEMOCRACY AND Distrust: A THEORY OF JUdicIAL REVIEW (1980); Edgar Bodenheimer, JuRISPRUdence: THE PhILOSOPHY AND METHOD OF THE LAW (rev. ed. 1974); ROBERT Nozick, ANARCHY, STATE, AND UTOPIA (1974); JOHN RAWLS, A THEORY OF JUSTICE (1971).

111 See generally Roberto MANGabeira Unger, LAW IN MOdERN SocIETy (1976); Harold Lasswell \& Myres Mcdougal, Legal Education and Public Policy: Professional Training in the Public Interest, 53 YALE L. J. 203 (1943). 
maldistributed across the population. ${ }^{112}$ His conclusion remains true today: "The blunt, inexcusable fact is that this nation, which prides itself on efficiency and justice, has developed a legal system that is the most expensive in the world, yet cannot manage to protect the rights of its citizens." 113 Although there may be no more court cases per capita than in the past, there are more statutes and regulations to negotiate, just as there are more medical tests and therapies for disease. Like medical students, law students often choose lucrative private practice specialties rather than public service, partly to repay the increasing cost of their educations. Specialties in both medicine and law are more rewarding, both in money and prestige, than primary care and general practice. The growth of large multistate and multinational law firms mirrored the consolidation of both hospital systems and insurance companies, resulting in higher compensation for partners and associates and higher fees for clients, ${ }^{114}$ although the recession has dampened that trend.115 Major law firms concentrate on providing services at rates that only large organizations and wealthy individuals can pay. Low and middle-income families and small businesses cannot afford much justice. Legal service organizations and public defenders are generally underpaid while reaching only a fraction of those who need their help. In this respect, the health care system performs somewhat better, because public and private health insurance, as well as uncompensated care pools, are available.

112 Derek C. Bok, A Flawed System of Law Practice and Training, HARVARD MAGAZINE 38, 38, 40 (May-June 1983), reprinted in $33 \mathrm{~J}$. LEGAL EDUC. 570, 570, 572 (1983).

113 Id. at 41.

114 Carrie Menkel-Meadow, Culture Clash in the Quality of Life in the Law: Changes in the Economics, Diversification and Organization of Lawyering, 44 CASE W. RES. L. REV. 621, 628, 631 (1994).

115 America's Law Schools and Firms: Trouble with the Law, THE ECONOMIST, Nov. 13, 2010, at 79, available at http://www. economist.com/node/17461573. 
Bok's report sparked many commentaries, but few concrete changes. ${ }^{116}$ Here, health law may offer some valuable perspectives. Because health lawyers often deal with issues of equitable access to health care, they should be particularly attuned to the ways in which laws promote or hinder access to justice. Thus, they may be alert to problems of justice and fairness in the legal system. ${ }^{117}$

The Affordable Care Act lays out a program for near universal access to health care. Although the ACA does not directly control the health care costs that created pressure for reform, it puts the cost of care on the agenda for future experiments and reforms. ${ }^{118}$ Perhaps it is time to initiate reform not only in legal education, but, as Bok urged, in the legal system as a whole. Real reform would go beyond ongoing efforts to improve law school curricula. Reform goals should include enabling access to essential legal services for the entire population. For example, adapting the model of medical residencies for graduates of medical schools, creating a one or two year residency program in which law graduates spend time working for low and middle-income clients under the supervision of licensed attorneys would give graduates important practical experience and expand the services available to those in need. ${ }^{119}$ To integrate such training and experience into the

116 See, e.g., Deborah L. Rhode, The Rhetoric of Professional Reform, 45 MD. L. REV. 274 (1986); Roger Cramton, The Trouble with Lawyers (and Law Schools), 35 J. LeGAL EdUc. 359 (1985); David M. Trubek, Comments on the Bok Report - A Strategy for Legal Studies: Getting Bok to Work, 33 J. LEGAL EDUC. 586 (1983); Alfred F. Conrad, The Law School's Responsibility for the Quantity of Justice, 33 J. LEGAL STUD. 600 (1983); Stephen Gillers, Great Expectations: Conceptions of Lawyers at the Angle of Entry, 33 J. LEGAL EDUC. 662 (1983).

117 See generally JEROLD S. AUERBACH, UNEQUAL JUSTICE: LAWYERS AND SOCIAL CHANGE IN MODERN AMERICA (1976).

118 See An Act Improving The Quality Of Health Care and Reducing Costs Through Increased Transparency, Efficiency And Innovation, 2012 Mass. Acts, in which Massachusetts enacted payment reform legislation intended to slow the growth of health care costs, only a few years after enacting health care reform.

119 For early recommendations for similar clinical years, see CARNEGIE, REPORT, supra note 37, at 192; StEVENS, supra note 50, at 242-3. An alternative might be to borrow an approach from European legal 
curriculum before graduation, the third year of law school could be transformed into an analog of medical school clerkships. Third year students could work in government agencies, non-profit, and legal service organizations. There should be plenty of opportunities for such placements in the health care system, but similar opportunities could surely be found in education, housing, family law, energy and environmental placements. In this way, legal education might begin to respond more effectively to both the Ivory Tower and Social Justice critiques and improve access to justice for everyone.

\section{Conclusion}

Arguments over the constitutionality of the ACA - in the courts, in public debates, in scholarly articles, and blogs illustrate the pervasiveness of health law issues in society. It also demonstrates that many participants in that debate, both those for and against the ACA, remained wedded to theories that have become disconnected from twenty first century realities. Legal education may have something to answer for in this respect. The more law moves away from strict principles into nuanced adjustments to new circumstances, the more lawyers will need to understand the circumstances. As the search for more affordable, responsive, and responsible legal education continues, it is worth emulating the best features of health law. Health law scholars should be proactive in translating their successes into broader curriculum changes, especially attention to context, both in theory and practice. Because the context includes how law affects society at large, meaningful reform should adopt as its ultimate goal extending affordable access to justice for all.

education, which requires law graduates who pass a partial licensure examination to practice for two or three years (much like a medical residency) and then take another examination to qualify for full licensure. 